\title{
PROTECTION OF AVIFAUNA FOR THE PROVISION OF KYIV URBAN ECOSYSTEM STABILITY
}

\begin{abstract}
The transformation of ecosystems at urban territories imposes serious threats to the well-being of its inhabitants, both human and non-human. Modern cities represent a random combination of natural and technogenic landscapes, which often have no connections, and therefore are not able to support animal populations. However, the stability of such clustered ecosystem is impossible without the provision of stable flow of energy and matter ensured by living organisms. Being vulnerable to the negative factors of the urban environment, animals are also able to reflect its condition, so by contributing to the diversity of urban fauna it is possible to increase the overall quality of living conditions in a city. However, animals in cities are represented by insects, rodents, domesticated animals and single ubiquist organism, which either cannot be monitored, form real populations or are not desired. Therefore birds are considered to be that part of zoocenosis, which are worth investing efforts in support and development. The research has been conducted to study the avifauna of Kyiv City and major threats to its diversity and populations. The major risks for birds at the territory of Kyiv are formed by the fragmentation of natural landscapes, introduction of new species, pollution of the environment, waste accumulation and physical factors of pollution, namely light and noise. In order to provide the conservation of existing bird associations it is offered to unite a chain of landscapes, joined by close location, well preserved phytocoenosis and favourable conditions for birds' living activity, into protected objects with corresponding legal status. The fundamental element of the future protected areas is chosen to be water bodies of the city. The analysis of suitable and available areas has output a structure of 4 cores, based on lakes of Svytoshynsky, Osokorky, Obolon and Desnyansky districts of Kyiv. They all possess the necessary feature to apply for protected status and are already habitats of urban avifauna. The success of this initiative should be supported by the creation of single management body for all protected areas of Kyiv. The investments in the implementation of the project are estimated and cover organizational and technical actions.
\end{abstract}

Keywords: biodiversity; ecosystem; bird communities; environment components; protected areas.

Introduction. The process of urbanization became the actual trend of the development of any country. Unfortunately, so did the challenges, accompanying this kind of pace of progress: micro and global climate changes, air pollution, water quality deterioration, soil fertility degradation, social and economic inequality enhancing and simply lack of free and personal space. Another issue is growing predominance of man-made objects and structures surrounding the residents of urban territories.

Well known and long proved is the fact, that artificial systems of any kind cannot permanently sustain themselves; this only further emphasizes the need to preserve natural elements in cities, to ensure their stability. In other words, the efforts must be invested in saving and creating comfortable living conditions for all groups of city inhabitants, not only humans.

Birds, also called - avifauna, - are also typical for all urban systems and highly susceptible to surrounding changes, they have relatively shorter lifespan, which makes it easier to monitor the effects of the city. In addition, they actually participate in urban life mode, its structural elements and features, sometimes to an extent that they depend on them, contributing to the need in stability and high quality of environment in cities. So, the aim of the work is to study the threats, imposed by the Kyiv urban ecosystem on avifauna, and recommendations for avifauna protection.

Urban avifauna in research works. In the light of continuous expansion of artificial domain and conversion of natural lands, urban environments can no longer be viewed as a lost habitat for wildlife, but rather as a new habitat that, with proper management, has the potential to support diverse communities (including avian ones) (McDonnell \& Pickett, 1990; McKinney, 2002). During the last two decades urban ecosystems have become a new environmental challenge in conservation, restoration, and reconciliation ecology, especially since designing sustainable urban ecosystems that support species-rich communities also includes maintaining key ecosystem services, such as clean air and water, waste decomposition, pest control, etc. (Shochat, Lerman \& Fernandez-Juricic, 2010; Miller \& Hobbs, 2002; Rosenzweig, 2003).

Currently, ecologists are trying to understand better the

\section{Інформація про авторів:}

Радомська Маргарита Мирославівна, канд. техн. наук, доцент, кафедра екології. Email: m.m.radomskaya@gmail.com; https://orcid.org/0000-0002-8096-0313

Горобцов Інокентій Владиславович, фахівець відділу управління інноваційними проектами освіти, здобувач, кафедра екології. Email: inimyo7@gmail.com; https://orcid.org/0000-0001-6890-4370

Цитування за ДСту: Радомська М. М., Горобцов І. В. Protection of avifauna for the provision of the Kyiv urban ecosystem stability. Науковий вісник НЛТУ України. 2019, т. 29, № 3. С. 60-63.

Citation APA: Radomska, M. M., \& Horobtsov, I. V. (2019). Protection of avifauna for the provision of Kyiv urban ecosystem stability. Scientific Bulletin of UNFU, 29(3), 60-63. https://doi.org/10.15421/40290313 
drivers of urban bird population dynamics and community structure, the role of habitat and vegetation profile vs. predator - prey interactions, inter-specific competition for food and other resources and interrelations of populations with cities functioning. By now, the relevant researches have been performed on multiple cities and countries, including Canada, Germany, Indonesia, Israel, Poland, etc. (Melles, 2005; Shwartz, Shirley \& Kark, 2007; Tryjanowski et al., 2017; Silva et al., 2015; Pudyatmoko \& Nurvianto, 2009). In Ukraine this topic is also a novelty, and popular among biologists - there available works by Shupova T. V., Stankiewicz O. I., Ilyinsky S. V., Bokotey A. A., Chaplygina A. B. (Shupova, 2014; Stankiewicz, 2004; Ilyinsky, 2008; Bokotey, 2008; Chaplygina, 2010).

Among the recent developments, the separate ecology 'in' and 'of' cities should be highlighted. The majority of urban ecology research to date falls into the category of the ecology 'in' cities. Nowadays there are not so many examples of ecology 'of' cities studies, yet the scientists recognize the necessity of active development of this branch for advancement and enhancement of the understanding of urban ecosystems. All this dictates the need for more fundamental and generalized studies to find terms and conditions beneficial for humans, urban systems and inhabitants in consideration (birds in this case).

Urban ecosystem as a habitat. Urban systems are quite different from natural ones in many ways:

- Presence of completely new separate technogenic urban component, which represents a set of purely artificially created elements, mostly managed only by human activity and defining conditions of living activity of all representatives and inhabitants of such system (e.g. road and transport network, industrial activity represented by factories and enterprises, residential areas etc.);

- Absence of self-management and self-sustaining - once urban system is created, it cannot exist by itself and requires sufficient attention and care from human to perform its given functions, therefore such system cannot be completely technogenic and human still needs to manage the share of natural component, e.g. the percentage of green vegetation or the presence of pests;

- High degree of fragmentation opposite to natural systems homogeneity - the introduction of artificial and technogenic elements into natural system alters it through disruption of the original natural bonds and division of ecosystem body;

- High number of introduced alien and exotic, which leads to alteration, transformation or creation of new unapparent types of interactions between organisms, redistribution of resources and niches.

Even though urban ecosystems are created by humans and for humans, they still cannot exist completely separately from nature, as it was mentioned before. As the cycles of energy, matter and information are required of the system to be viable, the other living organisms are necessary to maintain it. And that is why the last two points from the list above are gaining extreme interest and importance.

Nevertheless, wildlife is still present at urban areas, even though most typical habitats are lost or distorted and trophic chains are strongly modified. Considering the birds as the central topic of this research, we can sum up features of their populations composition and diversity in the urban system borders as following: urban system demonstrates higher bird densities and abundances, while the species diversity is generally lower or the same compared to the surrounding natural ecosystems.

The major threats for the Kyiv city avifauna. The analysis shows that as of the most fundamental threats to avifauna, like fragmentation of habitats, the city is still at satisfactory level as of preservation of natural green areas inside city borders. Kyiv remains one of the unique European capitals, which preserved significant areas of valuable natural areas. The city is surrounded by an almost continuous ring of forests. More than half of the territory of Kyiv (approximately 65\%) is occupied by natural and artificial forest parks and parks, green spaces of common use and water bodies (lakes and ponds - about $2 \%$ ). Nevertheless, in city strong tendency for the decrease of green vegetation areas due to investments into residential construction is observed.

The next issue is invasive and alien species - here Kyiv is not very different from other urban environments of the world. Ukrainian ornithologists distinguish several pathways of introduction of new bird species to the city:

- natural way, where birds come to the city by themselves looking for more comfortable living conditions - food, warmth, shelter etc. (e.g. raven);

- birds travel from one city to another, choosing new more available locations during migrations (e.g. collared dove, serin or blackbird);

- birds that fled from nurseries, private farms and zoos, the so-called "runaway" of "fugitive" birds: for example, wood or Carolina ducks and ruddy shelduck that lived in the zoo and now are near the Bortnychy water-treatment plant, where temperature does not drop lower than $20^{\circ} \mathrm{C}$ even during winter;

- growing numbers of birds' natural enemies - predators.

Generally, Kyiv birds diversity aligns with overall world urban trend, that state that $80 \%$ of urban birds are 4 species (pigeons, sparrows, starlings and swallows) (Miller \& Hobbs, 2002; Shwartz, Shirley \& Kark, 2007; Silva et al., 2015). Therefore, the growing diversity will be of benefit for city, if newcomers will not threaten the old residents.

The situation with nutrition base for birds is similarly controversial. With such an amount of green plantations as in Kyiv, there should be no problems for birds to find food. Yet the thermal regime of the city and global issue of climate change influence lifecycles of plants and insects, producing periods with excessive and insufficient fodder. The city expansion also causes transformation of croplands increasing distances, which needed to be traveled for birds, which feed there. In these conditions many birds' species are bound to turn to refuse option in light of its permanent availability, abundance and easiness in obtaining. And in cold seasons it can even be an only option for city birds.

Another category of dangers, faced by urban avian populations, include disturbance from humans (noise, light and recreation), development of industrial and constructional activity, environment pollution and waste, which cause chemical intoxication (both respiratory and digestive).

Actions to support the bird populations in the Kyiv city. In order to support the avifauna of the Kyiv city it is necessary to conserve integral patches of suitable habitats with the city, which will be protected with certain protected status. This will give the necessary conditions for bird communities nesting, reproduction, feeding and diversification. It will also protect them from such negative impacts of urbanization as noise and light pollution and conversely contribute to the mitigation of the air pollution. The core of such protected areas should be water bodies of any kind, primarily lakes, as they have always been a good background for bird populations.

To choose target objects for the purpose of the project, the following traits were put forward: presence of natural of 
artificial vegetation around the water body, recreational or cultural value, habitat to any valuable species, sanitary condition. These factors are necessary for both well-being of bird communities and for application to obtain protected status for them. Additionally, the acquisition of protection status will contribute to the solution of other mentioned issues of those ecosystems: prohibition of construction; prohibition of waste storage; prohibition of hydrotechnical works; protection of soil cover; protection of phytocenosis; active information policy, which will contribute to the support of the official nature conservation and stability establishment efforts.

Kyiv has a unique hydrographic system, which includes 129 lakes, 102 ponds and 43 small artificial reservoirs. There is a range of bigger lakes at the Left Bank of the capital, they are mostly of natural origin and sometimes form clusters, which is especially important for any wildlife habitat presence. Most of them are oxbow lakes of the ancient riverbed of the Dnipro. In turn, the Right Bank has a higher number of artificial lakes, or natural ones, which are severely affected by human activity; they are usually smaller and more separated from one another.

Based on these considerations, a few lakes have been chosen expand the protected network: Almazne, Babyne, Radunka, for the Core 1 of the network in the Left Bank (Dniprovsky and Desniansky districts), and Kyrylivske, Yordanske and Verbne for Core 2 in the Right Bank (Obolonsky district).

The third Core is to be located on the Right Bank, and includes the cluster of Sviatoshynski ponds (ponds № 14, 15 and others nameless). All of them are quite big (10 $37 \mathrm{ha}$ ) and are attached to the Sviatoshynskyi forest from one side. Unfortunately, this ecosystem has already been damaged in the process of melioration and drying at the beginning of $2000 \mathrm{~s}$. Nonetheless, they still remain a calm natural place which possesses undeniable conservation and ornithology value - 33 species of birds were spotted on and around lakes, 16 of which are water bound, at least 4 - nesting, and 2 - protected by the Red Book of Ukraine: black kite (Milvus migrans Boddaert) and white-tailed eagle ( $\mathrm{Ha}$ liaeetus albicilla Linn).

The fourth Core includes the most difficult and questionable, yet important objects, that really need protection. It is located on the Left Bank and consists of the Vyrlytsia lake and Osokorky lakes. All of them are of mixed origin and belong to the 10 biggest lakes of Kyiv (Vyrlytsia 110.1 ha, Tiahle - 135 ha, Martyshiv - 90.4 ha, Nebrezh 44.1 ha). Lakes are not surrounded by a big amount of vegetation, yet they are connected through a quite dense shrub-swamp ecosystem. However, due to the residential infrastructure on one side and some energy and waste disposal on the other, the environmental state of lakes still needs to be verified. The last and one of the most pressing issues is the fact that Osokorky lakes are subject to construction according to the General Plan for the Development of Kyiv, which is massively opposed by the concerned public. All of mentioned problems could be solved through the creation of protected area, since it is an important habitat for many water bound and other birds, as well as marsh organisms: amphibians, reptiles, insects, but most importantly fishes: Vyrlytsia is inhabited by 30 fish species, two of which are in the Red Book of Ukraine.

Some of the offered sites are already protected objects (Radunka Lake and Romanivske swamp adjoined to the
Svyatoshynsky cluster), or await for solution from the authorities (Babyne Lake), while others still need some research and document preparation, therefore the work on the project is in progress.

The second of suggested solution has been developed and launched in collaboration with National Ecological Center of Ukraine. It concerns the creation of the Kyiv United Protected Areas Administration. We believe that the competent managerial body will increase the comfort for birds through the efficient care being applied. The functions of this administrative body should include:

1. Landscaping and maintenance of all natural protected areas and objects;

2. Work towards organization and control of borders and zoning for sites;

3. Actual protection of areas and objects, through physical (e.g. fencing, guarding), social (e.g. information work, educational actions, excursions) and legislative means, including legal prosecution in case of laws violation;

4. Surveillance and monitoring of species and communities;

5. Educational work, organization of excursions, collection of data on environmental conditions, species inhabiting areas;

6. Providing a proper media network for communication and reporting on progresses, challenges, assistance possibilities etc.

Obviously, such a massive body will need a big staff, as well as local point-like divisions, which can be the already existing PAs administrations, where they are available. Nevertheless, the benefit of such management will be first of all in coverage of all objects lacking such administrations and actual protection and care, integration of this network into overall Ukrainian grid and gathering experts in the field, who will work towards keeping sustainability of the city. The idea has already been delivered by the NECU to the administration of Holosiivsky NNP, which can become a starting platform for the full implementation of the proposal.

Finally, it is very well understood, that such massive actions could not be implemented at once, and require considerable paperwork, discussion and resources allocation. The latter one is crucial for acquiring support from the authorities and making the plans real. The necessary capital investments are roughly estimated as 2.5 million UAH, spent on construction of service buildings, fencing, establishment of signs, construction of feeding boxes for birds, observation points establishment, territory cleaning and arrangement. Generally speaking, those are considerable, bur realistic costs for one city, especially in comparison with EU costs allocation on similar projects in the field.

Conclusions. The capital city of Ukraine offers a valuable natural and semi-natural background for the settlement of birds of diverse ecological niches. However, the growing construction intensity leads to fragmentation and even elimination of the potential habitats for avifauna. Urban conditions, being considerably different from the natural ones, are still attractive for birds, despite a variety of threats, ranging from environment pollution to invasive species. In order to support the populations of birds in the city and contribute to their diversification, it is offered to create the central authority for management of natural areas, to be conserved by protected status. The cores for the creation of the protected areas network within the city have been chosen to be lacustrine ecosystems. The necessary investments into the project implementation, already supported by certain NGOs, have been estimated and demonstrate affordable level. 


\section{Перелік використаних джерел}

Bokotey, A. A. (2008). Changes in breeding avifauna of Lviv City and their causes (basing on the results of compiling the ornithological atlases in 1994-1995 and 2005-2007). Scientific bulletin of Uzhhorod University. Ser. Biology, 23, 17-25.

Chaplygina, A. B. (2010) Eco-faunistic analysis of avifauna of urbolandscapes (the case study of the Zhuravlivs'kyi hydropark in Kharkiv). Natural almanac, Ser. Biological sciences, 14, 187-199.

Ilyinsky, S. V. (2008). The current state of the ornithofauna of Khmelnitsky. Interdepartmental scientific thematic collection "Poultry Farming", 61, 48-63.

McDonnell, M. J., \& Pickett, S. T. A. (1990). The study of ecosystem structure and function along urban-rural gradients: An unexploited opportunity for ecology. Ecology, 71(4), 1231-1237. https://doi.org/10.2307/1938259

McKinney, M. L. (2002). Urbanization, biodiversity, and conservation. Bioscience, 52, 883-890. https://doi.org/10.1641/00063568(2002)052 [0883: UBAC]2.0.CO;2

Melles, S. J. (2005). Urban Bird Diversity as an Indicator of Human Social Diversity and Economic Inequality in Vancouver, British Columbia. Urban Habitats, 3(1), 25-48.

Miller, J. R., \& Hobbs, R. J. (2002). Conservation where people live and work. Conservation Biology, 16, 330-337. https://doi.org/10.1046/j.1523-1739.2002.00420.x

Pudyatmoko, S. K., \& Nurvianto, S. (2009). Role of Urban Environment on Conservation of Birds Diversity in Java, Indonesia. Jour- nal of Biological Sciences, 9(4), 345-350. https://doi.org/10.3923/ibs.2009.345.350

Rosenzweig, M. L. (2003). Win-Win Ecology. Oxford, UK: Oxford University Press.

Shochat, E., Lerman, S., \& Fernandez-Juricic, E. (2010). Birds in urban ecosystems: population dynamics, community structure, biodiversity, and conservation. Urban Ecosystem Ecology: Agronomy monograph, 4, 75-86. Madison: ASA-CSSA-SSSA. https://doi.org/10.2134/agronmonogr55.c4

Shupova, T. V. (2014). Avifauna in settlement zone of Kiev. (Ser. Biology). The Journal of V. N. Karazin Kharkiv National University, $21,1112,83-91$.

Shwartz, A., Shirley, S., \& Kark, S. (2007). How do habitat variability and management regime shape the spatial heterogeneity of birds within a large Mediterranean urban park? Landscape and Urban Planning, 84 ,

219-229. https://doi.org/10.1016/j.landurbplan.2007.08.003

Silva, C. P., Garcia, C. E., Estay, S. A., \& Barbosa, O. (2015). Bird Richness and Abundance in Response to Urban Form in a Latin American City: Valdivia, Chile as a Case Study. PLoS ONE, 9(10), 120-138. https://doi.org/10.1371/journal.pone.0138120

Stankiewicz, O. I. (2004). Fauna and bird communities of Uzhhorod in breeding period. (Ser. Biology). Scientific bulletin of Uzhhorod University, 15, 123-128.

Tryjanowski, P., Mikula, P., Morelli, F., \& Krištin, A. (2017). Bird diversity in urban green space: A large-scale analysis of differences between parks and cemeteries in Central Europe. Urban Forestry \& Urban Greening. https://doi.org/10.1016/j.ufug.2017.08.014

М. М. Радомська, І. В. Горобцов

Національний авіачійний університет, м. Київ, Украӥна

\section{ЗБЕРЕЖЕННЯ ОРНІТОФАУНИ ДЛЯ ЗАБЕЗПЕЧЕННЯ СТАБІЛЬНОСТІ УРБОЕКОСИСТЕМИ КИЄВА}

Трансформація екосистем на міських територіях створює серйозні загрози для нормальної життєдіяльності їі жителів, як людей, так і тварин. Відомо, що сучасні міста $є$ нерівномірним поєднанням природних і техногенних ландшафтних елементів, які часто не мають зв'язків і тому не здатні підтримувати популяції тварин. Однак стабільність такої кластерної екосистеми неможлива без забезпечення неперервного потоку енергії і матерії, що здійснюють живі організми. Встановлено, що учасники міського зооценозу здатні відображати його стан, тому сприяючи його різноманітності, можна підвищити загальну якість умов життя в місті. Вузький діапазон груп живих організмів, що проживають на території міст, зумовив вибір пташиних угруповань як найперспективнішого об'єкта для реалізації природоохоронних заходів. Проаналізовано основні загрози для орнітофауни міста Києва. Обгрунтовано необхідність виділення на території міста ландшафтів, об'єднаних близьким розташуванням, добре збереженими фітоценозами та сприятливими умовами для діяльності птахів, у захищені об'єкти з відповідним правовим статусом. Як основу для потенційних природоохоронних об'єктів запропоновано озера та ставки міста. На основі аналізу придатних і доступних територій сформовано 4 ядра у різних районах Києва. Для успішної реалізації проекту рекомендовано створити єдиний орган управління для всіх природоохоронних територій Києва. Розраховано вартість реалізації проекту.

Ключові слова: біорізноманіття; екосистема; пташині угруповання; компоненти навколишнього середовища; природоохоронні об'єкти. 